\title{
ОБРАЗ РОМАНТИЧНОГО ПОЕТА-МАНДРІВНИКА У ТВОРЧОСТІ ОЛЕКСАНДРА ОЛЕСЯ ТА ЄВРОПЕЙСЬКИХ СИМВОЛІСТІВ
}

\author{
Ігор Цуркан \\ Херсонський державний університет Херсон, Україна \\ ORCID: 0000-0002-8200-5299
}

\begin{abstract}
Резюме. У статті розглядається образ романтичного поета-мандрівника у творчості Олександра Олеся та європейських символістів. Репрезентовано настрої людини, iiі почуття за допомогою орнітоморфних символів, що розкривають відчуття незгоди зі світом, оточенням. Окреслено функціонування образів пустелі та дороги, що можуть виступати формантами загальних психологічних станів епохи і характеризувати особисті переживання та настрої поетів.
\end{abstract}

Ключові слова: образ, природа, символ, символізм, мотив, душа.

Європейська поезія презентувала постійні скарги на розривання душ, які ламались від великих розчарувань, нарікання на те, що ні в чому немає надії, ніщо більше не зможе врятувати поета, збагаченого досвідом болю. Одночасно ж поети, які пишуть про власний гіркий досвід, висміюють тих, хто обрав іншу дорогу і добровільно відмовився від свідомого поринання у глибини болісного досвіду. Популярний на початку століття Моріс Метерлінк був переконаний у тому, що людина як істота роздвоєна й одночасно належить до двох світів: світу відчуттів і світу трансценденції. Принцип двоїстості, антагонічного співіснування в людині реальної і потойбічної сфери досить виразно проявилося в художній спадщині європейських митців.

У європейській поезії другої половини XIX століття відбулася глобальна переоцінка цінностей через перевагу раціоналістичних явищ у житті суспільства, що втратило віру в непохитні ідеали духовності й віддало перевагу матеріальним цінностям. Долі багатьох поетів Франції стали прикладом аутсайдерства, душевного смутку, відчуженості внаслідок естетичного виклику, який вони кинули суспільству. Символісти порушували питання дисгармонії особистості, співвідношення юрби й Поета (типовий романтичний конфлікт, творчо розвинутий модерністами), життя і смерті, демонструючи протест проти міщанського життя, 
яке породжувало страждання, що спонукало особистість не сприймати недосконалу сучасну йому дійсність. Поезія зуміла символічно передати відповідні настрої та емоції доби, створити узагальнений образ переживань людини fin de siècle.

Мотив подорожі - мандрівки, поневірння, пошуків - надзвичайно активний і у польській літературі. Сягаючи традицій романтизму і байронічних героїв, що їх було чимало у польській літературі (найбільш канонічні з них - Пілігрим із Кримських сонетів Адама Міцкевича й Кордіан з однойменної драми Юлія Словацького), концепт мандрів як нового способу осягнення світу знайшов нішу для реалізації й у ранньо-модерністичній літературі, зокрема в поезії Леопольда Стаффа і Казимежа Пшерви-Тетмаєра.

Інтерпретація творчості Олександра Олеся, що репрезентована дослідженнями літературознавців того часу Івана Франка, Лесі Українки, Олександра Білоусенка, Сергія Єфремова, Миколи Євшана, Остапа Грицая, Миколи Новиченка, Григорія Костюка, Віктора Петрова, - і нині $\epsilon$ предметом актуальних наукових обговорень і дискусій. У дослідженнях останніх років Ростислава Радишевського, Ольги Камінчук, Петра Ляшкевича та багатьох інших авторів заперечуються спроби примітивізації та спрощеного трактування спадщини Олександра Олеся. Окрім того, кожна поетична особистість відчувала глибоко внутрішні, притаманні тільки їй відчуття незгоди зі світом, оточенням, відрив від реальності, що також можна розцінювати як прояви комплексів епохи. Відтак потреба об'єктивного наукового прочитання і осмислення художнього доробку Олександра Олеся - нагальна й очевидна. Саме цим і зумовлена актуальність пропонованого дослідження.

Метою статті є змалювання образу романтичного поета-мандрівника у поезії Олександра Олеся та європейських символістів, що долає свій життєвий шлях в усій його діалектичній складності та внутрішній суперечливості. Сьогодні жоден із дослідників художнього письменства не наважиться відстоювати спроби радянського літературознавства представити Олександра Олеся поетом, що прагнув відсторонитись від драматичних подій суспільного життя, не реагував безпосередньо на гострі запити свого часу.

Український митець опинився не тільки на межі століть, але й на межі двох світобачень: старого - реалістичного, історичного, традиційного, героїчного і нового - ірраціонального, індивідуалістського, позачасового, трансцендентного, розпачливого. Це визначило основні суперечності епохи, які, безумовно, відбились у творчості Олександра Олеся.

Олесева філософія життя у їі вічному русі, мінливості, перетвореннях, єднанні обумовило завдання нашого дослідження - визначити функціонування романтичного образу поета-мандрівника у поезії 
Олександра Олеся та європейських символістів, що грунтуються на вічному пошуку віри, краси та правди. Мета і завдання дослідження зумовили використання таких методів: культурно-історичного, біографічного, рецептивної естетики, герменевтичного, інтерпретаційно-текстового аналізу.

Типологічною характеристикою образу символістського проклятого Поета кінця століття стає нонконформізм, неприйняття ницості існування, відчуженість та визнання своєї непотрібності народові.

Відомо, що тема прокляття розробляється у засновника французького символізму Шарля Бодлера, зокрема в його вірші Благословення (1856), що відкриває Сплін і ідеал - перший цикл поезій Квітів зла (1857). У цьому поетичному творі зображено трагічну долю митця, народження якого супроводжується гнівними прокльонами матері:

Коли з'являється Поет на цьому світі,

Його родителька від розпачу й журби

На Бога кидає прокльони ядовиті,

I співчутливо Бог сприймає ті клятьби ${ }^{1}$.

Поет постає в образі “поглума”, “блазня”, що відчуває приниження не тільки з боку натовпу, але й від найдорожчої у світі людини - матері, яка позбавила його ще з дитинства материнської ніжності й тепла. Таким свідомо загостреним сюжетом автор увиразнює трагізм ситуації “проклятого поета":

Чом народила я цей поглум? Чи не краще

На світ спровадити гадюк ціле кубло?

Будь прокляте моє кохання негодяще,

I лоно трепетне, що блазня зачало².

Усвідомлюючи свою приреченість як ізгоя в натовпі й сім’ї, ліричний герой самовіддано зберігає вірність своїм непохитним ідеалам у меркантильному суспільстві. Нехтуючи презирством натовпу, він вбачає своє місце поряд із Богом, досягаючи його шляхом страждання на Землі:

Поетові в рядах священних Легіонів

Ти місце бережеш; поета просиш ти

На вічне торжество ясних Чеснот і Тронів,

На свято Людськості, на учту Доброти

Ш. Бодлер, Поезї̈, пер. $з$ франц. Д. Павличко, М. Москаленко, ред.-упоряд. М. Москаленко, авт. вступ. слова Д. Павличко; авт. післям. Д. Павличко, Київ 1999, с. 35.

2 Там само.

3 Там само, с. 37. 
Тема протиставлення поета натовпу розвивається у вірші Альбатрос (1859) Бодлера. Поет ототожнює себе з альбатросом, сильним та могутнім морським птахом, над яким чинять наругу матроси, що спіймали його під час подорожі. Звертаючись до основних топосних категорій, Бодлер констатує той факт, що альбатрос у небі - це величний птах, “ясних висот владика", а на землі “володар блакиті" стає “незграбним та смішним" для матросів. Емоційна атмосфера, яка передає його душевний та фізичний стан, створюється за допомогою влучних порівнянь:

На палубу несуть ясних висот владику.

I сумно тягне він приборкане крило, Що втратило свою колишню міць велику, Мов серед буйних вод поламане весло ${ }^{4}$.

Незважаючи на кумедний вигляд птаха, що почувається зацькованим у ворожому середовищі, справжніми потворами виступають матроси, які знущаються над альбатросом. Вони позбавлені почуття жалю до його душевного страждання:

Той тютюновий дим у дзьоб йому пускає,

А цей, дратуючи, кульгає, мов кривий 5 .

Ліричний герой, як і птах, відчуває себе в небі володарем блакиті й духовно сильною особистістю, а на землі його високі моральні принципи та ідеали стають непотрібними в деградованому суспільстві, де панує жага до влади й багатства. Так, Поет в інтерпретації Бодлера - духовно могутня особистість, яку нехтує жорстоке людство за його неординарність:

Поет подібний теж до владаря блакиті,

Що серед хмар летить, мов блискавка в імлі.

Але, мов у тюрмі, в юрбі несамовитій

Він крила велетня волочить по землі'

Типологічно близькими є поетичні твори Альбатрос Шарля Бодлеpa, Альбатрос Казимежа Тетмаєра, Альбатрос Костянтина Бальмонта, В болоті жаби рай знайшли... Олександра Олеся та Сердие к солниу тяготеет... Федора Сологуба. У поезіях представлено вертикальну систему образів: “височінь” - як символ духовної свободи, сфера життедіяльності величезних птахів (альбатросів, орлів) та “земля", яка уособлює царство глупоти та ницості. Символічні образи орла і альбатроса

Там само, с. 288.

Там само.

Там само. 
в поезіях Тетмаєра, Олеся, Бальмонта, Сологуба є уособленням високої духовності (“О, блаженство быть сильным и гордым и вечно свободным” (Бальмонт) 7 , "Cisza na okeanie, nie drgnie jedna fala, / ciemno-modra płaszczyzna nieruchomo leży; / na fali, skąd już nie znać sinych wstąg wybrzeży, / siadł albatross od lądów i ludnych wysp z dala..." (Тетмаєp) ${ }^{8}$ на відміну від сірої маси - “жаб”, “сірих мишей”, які забезпечили собі безтурботне існування в соціумі - “болоті” (Олесь): “В болоті жаби рай знайшли / I там плодились, згнивали, / А десь над ними клекотали / В повітрі чистому орли” (Олесь) то тащат по дворам / Восходи же выше, выше / Высота нужна орлам" $(\text { Сологуб })^{10}$. Задоволеність жаб та сірих мишей своїм життям відображає людство, яке втрачає духовні цінності. Площина ницого існування сконцентрована в топосі “болото” (Олесь) та “долина” (Сологуб) з його характерними ознаками: “туркіт жаб”, “дух гнилий”, “смердюче багно”, “маленький флюгер з жерсті”. Експресивні дієслова (“плодитися”, “зневажати”, “приплутатися”, “згнивати”) оприсутнюють сферу буття його мешканців. У Олеся, на відміну від Бодлера, Тетмаєра, Бальмонта та Сологуба, в образі “орла", що “спускається до болота", імплікується поет-патріот, який виливає палкий гнів на бездуховне суспільство, та відкрито заявляє, що він не є слугою народу, бо не бачить можливості змін у затхлій та статичній буденності. У поетичному творі Альбатрос Тетмаєр зумів змалювати романтичні почування, поривання у світ гармонії та краси ("Wówczas na wielkich skrzydłach z szumem się podniesie, / wrzący ocean muśnie po spienionej grzywie, / rzuci się w pierś orkanom huczącym straszliwie / i ponad burzą w cichym zawiśnie bezkresie...") ${ }^{11}$, глибокі розмисли над сенсом буття (“A gdy burza ucichnie, gdzieś na skale dzikiej / usiądzie suszyć pióra od deszczu wilgotne / i patrząc w słońce, jak on, dumne I samotne, / słuchać w skałę bijących fal sennej muzyki") ${ }^{12}$, які переповнювали несамовиту, пристрасну “байронівську” душу ліричного героя. Безмежна влада та служіння альбатросів, орлів небесним ідеалам уособлюють у Олеся, Тетмаєра, Бодлера, Бальмонта та Сологуба дух свободи та світло небесної краси, недосяжні для земних істот. Відстороненість від профанного середовища, де митці відчувають свою

К. Бальмонт, Избранное. Стихотворения. Переводы. Статьи, сост., вступ. ст., ком. Д. Г. Макогоненко, Москва 1990, с. 65.

$8 \quad$ K. Tetmajer Poezje, Warszawa 1980, c. 78.

9 О. Олесь, Твори: в 2 т., упоряд., авт. передм. та приміт. Р. Радишевський, т. 1: Поетичні твори. Лірика. Поза збірками. 3 неопублікованого. Сатира, Київ 1990, с. 114.

10 Ф. Сологуб, Стихотворения, сост., подг. текста, примеч. М. И. Дикман Лкнинград 1978 , c. 89.

11 Tetmajer K., op. cit., s. 79.

12 Ibidem, s. 180. 
недосконалість та духовну неповноцінність, можна кваліфікувати як їх умовну “проклятість”.

Властивий символізму концепт естетико-центричної надреальності увиразнюється в образах "Божих птахів" - голуба та журавля, що набули у поезіях Олександра Олеся, Казимежа Тетмаєра, Леопольда Стаффа, Олександра Блока, Костянтина Бальмонта, Валерія Брюсова характерної для художнього мислення митців означеності. У символі журавля та “ніжної голубки" Олесь відтворює ідею неприйняття потворного ліричним героєм ("I журавлі кричать сльозами: «Умру, умру»") 13 та муки "(Стану я в своїй крові, наче голуб білий” ${ }^{14}$. У поетичній моделі світу борються дві протилежні сили: “свобода духу” "“Підбиті голуби знімались / 3 землі до променів ясних") $)^{15}$ - і кайдани духовного рабства (“І знов на землю обривались / I червоніли груди їх") ${ }^{16}$. Характерно, що для російських та польських символістів ці символічні птахи (голуб та журавель) співвідносні зі щирим коханням (“Девушка плакала ночью в тиши, - но о ком? / Голуби утром мелькнули и кинулись прочь” (Брюсов) $)^{17}$, їхній відліт корелює із невимовною тугою за красою рідних просторів (“А в небе журавлей летит толпа / И криком шлет прости в места родные” (Бальмонт $)^{18}$, “...Które o cichej godzinie zmierzchów wieczornych / Lecą w dal siną żurawianym kluczem / I, zawisnąwszy pod niebem, / Patrzą w dal oną, o której mi prawisz, / I powracają, kiedy sen mnie zmorzy, / I przyniesione nowiny mi gwarzą..." (Стафф) ${ }^{19}$, “Бачив раз журавлів, що одлітали на схід великими таборами. Був то осінній вечір, повний фіалкового смутку й тиші, як взагалі о ту пору в Татрах. Летіли кудись в безодню повітря, в далечінь, - такі похмурі, ніби й вони чули, що летять туди в останнє, що не повернуться ніколи, вже ніколи" (Тетмаєр) $)^{20}$, наближенням зими (“...Дни отлетевших журавлей / И, словно строгий счет мгновений” $(\text { Брюсов) })^{21}$ та усвідомленням вічного змагання радощів і болю на роздоріжжях людської долі (“Как от страницы до страницы / Вдаль потянули журавли" (Блок) $)^{22}$.

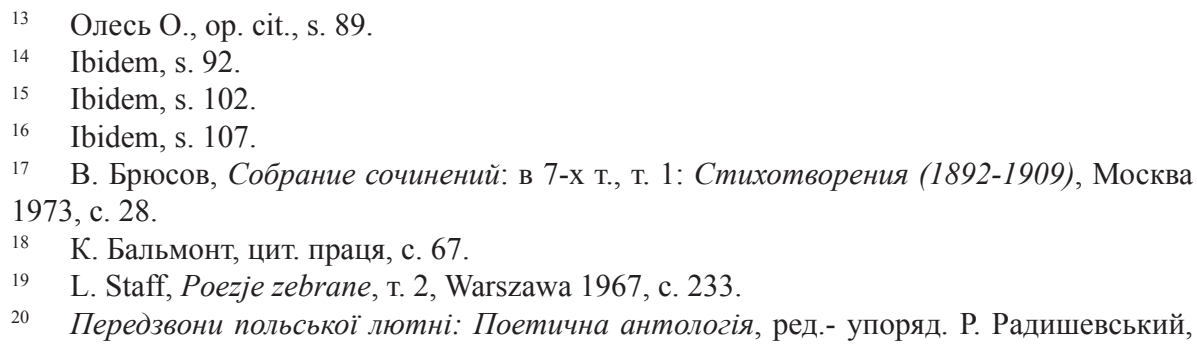

Передзвони польської лютні: Поетична антологія, ред.- упоряд. Р. Радишевський, Київ 2001. - s. 67.

${ }_{21}$ В. Брюсов, цит. праця, с. 78.

22 А. Блок, Собрание сочинений: в 8-ми т., под общ. ред. В. Н. Орлова, т. 3: Стихотворения и поэмы (1907-1916), Москва-Ленинград 1962, с. 34. 
Безмежна, вічна країна духовної свободи та нестримний політ думок на лоні спокою, тиші та краси інтерпретується в образах ластівок (“Я как ласточка крылат” (Брюсов) $)^{23}$, "Pożegnany jaskółek przedwieczornym świrem, / Padł dzień martwy na skrzepłych obłoków wezgłowia..." $(\text { Стафф) })^{24}$, "Les blés encore verts, les seigles déjà blonds / Accueillaient l'hirondelle en fleur flot pacifique" - "Пшениця ще зелена, жито вже світло-жовте / Зустрічали ластівку у своєму тихому морі” (Поль Верлен) ${ }^{25}$, "Порою перед мной толпа воспоминаний, / Порою ласточка над небом пронесется” (Бальмонт) ${ }^{26}$, жайворонків (“Ce lui dont les pensers comme des alouettes / Vers les cieux le matin prennent un libre essor" - "Ті думки, як жайворонки, / До небес зранку вільно злітають” (Бодлер) $)^{27}$, “Вспыхни, Солнце! Бог, воскресни! / Ярче жаворонка песни / Лейтесь в золото небес!" (B'ячеслав Іванов) ${ }^{28}$. Життєпростір людської істоти у безкінечному буттєвому вирі $з$ душевними переживаннями ототожнювався у Бальмонта 3 “плачем сірої чайки”, що створювало мальовниче тло природи:

Серая чайка плачет над морем,

В небе свинцовом тусклая мгла,

Aх, не расстаться с тягостным горем!

Где же мы были? Ночь уж прошла² ${ }^{29}$

Символічні птахи (чайка, зозуля, ластівка, жайворон) були для Олеся, внутрішньому єству якого було притаманне ніжне людське почуття до всього покривдженого та зневаженого в природі, “товаришами, друзями, братами, спільниками в щасті і тузі". I тому жорстокі реалії доби визначили своєрідне символічне тлумачення пташиного світу українським митцем, сповненого глибоким патріотичним почуттям. Так, душу Олеся (“Чужина - могила, чужина - труна, / Душа на чужині, як чайка, сумна") $)^{30}$ та образ обездоленої вітчизни, закованої в кайдани й ув'язненої, уособлювала чайка (“Пісню б заспівати та гірку, як сльози / Неньки-України, чайки при дорозі”) 31 , омріяну волю - жайворонок (“Жайворонком стати б! / Знятись над ланами”) ${ }^{32}$, щастя - пісня зозулі (“Слухаєм пісню

\footnotetext{
23 В. Брюсов, цит. праця, с. 43.

24 L. Staffцит. праця, с. 178.

25 П. Верлен, Лірика, пер. 3 франц. М. Рильський, М. Лукаш, Г. Кочур, Київ 1968, с. 45.

26 К. Бальмонт, цит. праця, с. 67.

27 Ш. Бодлер, цит. праця, с. 38.

28 В Иванов, Собрание сочинений: в 4-х т., ред. и ком. Д. Иванова, О. Дешарт, т. 3: Стихотворения, Брюссель 1979, с. 99.

29 К. Бальмонт, цит. праця, с. 368.

30 О. Олесь, цит. праця, с. 166.

31 Там само, с. 156.

32 Там само, с. 157.
} 
зозулі, / Щастя в серцях куємо”) 33, воскреслу надію (“Та пташка щебече співає мені, / Вже сонце, вже сонце в твоїй стороні, / Сам дух, дух народу прокинувся вже") - пророцтво ластівки ${ }^{34}$.

До семантичного кола творчості Олеся, Бальмонта та Іванова долучаються образи вогню та сонця, що контрастують 3 античною символікою птаха Фенікса $з$ вогненно-червоним та золотим кольором. Міфічна істота в російських символістів утверджувала ідею вічного відродження 3 попелу та безсмертя душі (“Как феникс, я хочу сгореть, / Чтобы восстать преображенным / И для мадонны умереть, / И для мадонны жить влюбленным" 35 у Бальмонта та "Вечно жив, в ком вечен жизни голод / O, учитесь Фениксом сгорать" у Іванова) ${ }^{36}$, тоді як український митець навіює відчуття повноцінного життя із мрією та вірою у звільнення рідного краю, обплутаного ланцюгами рабства (“Минули навіки дні чорних негод, / Живе Україна! I вільний народ, / Як з попелу Фенікс ожив і злетів / І поглядом зміряв він простір степів") ${ }^{37}$.

Мандрівний дух митця у вигнанні в стані відчуженості, покинутості та загубленості знайшов душевне умиротворення в лісі, що постав у Бодлера божественною, одухотвореною субстанцією, місцем перебування зневірених людських душ. Поступово заглиблюючись у лісне лоно природи - ірреальне буття панівної абсолютної краси та гармонії, ліричний герой виявився неспроможним звільнитися від земних пут життя, до якого його повертала подумки велика міць луни рогу, сповненої прикрої гіркоти трагізму буденності.

В інтерпретації Бодлера лебідь із трагічною долею всупереч ворожій дійсності уособлював бунтівника, виразника інтересів безпорадного людства, нездатного кинути виклик Богові за свої страждання в огидному буржуазному соціумі, який втілився у символі “засохлого струмка".

На творчості Стефана Малларме позначилися естетико-філософські засади Бодлера, які віддзеркалились у програмовому творі Лебідь та відповідали його естетичному кредо - "відображати не саму річ, а те, що справляє на неї враження" ${ }^{38}$. Сонет побудований на внутрішньому асоціативному зв' язку мотиву смерті з вічним прагненням митця до творчої самореалізації у світі, сповненого сумом, стражданням, самотністю. На початку твору автор відтворив картину “незайманого, палкого, чарівного дня" - ("le vierge, le vivace et le bel aujourd'ui") $)^{39}$, що майстерно вті-

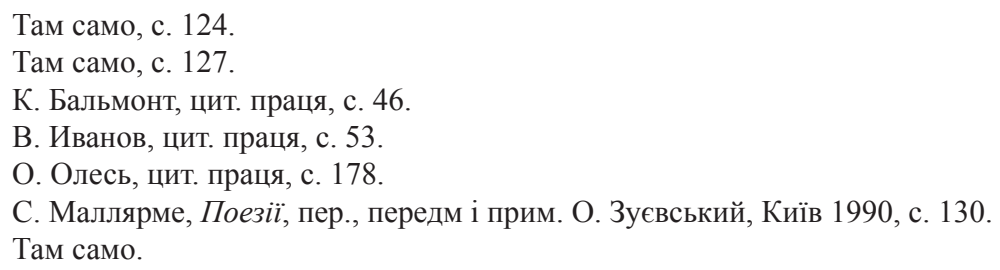


лювала ідею забуття, уповільнюючи рух людського життя у часовому та просторовому вимірі. Спільний з Бодлером поетичний світ ліричного героя Малларме, представленого в образі лебедя, відображав психологічно-настроєві розгалуження, що грунтувалися на його декадентському світовідчутті, визначеного песимістичним, трагічним пафосом, роздвоєністю особистості та дисгармонією. Лебеді, представлені у творах двох французьких символістів, намагалися подолати пута жорстокої реалії дійсності - “засохлого струмка" та “покритого снігом озера", мріючи про неосяжний світ Прекрасного. Але обидва йшли до своєї мети різними шляхами в залежності від свого життєстверджуючого кредо. Так, ліричний герой в образі лебедя Бодлера не підкорився депресивному настрою, усвідомлено тікаючи із звіринця вже нещасною калікою, але в пошуках рідного озера. У цьому випадку митець, уособлюючи величного білого птаха - символу відродження, зайняв активну, дієву позицію у відповідності з особистим внутрішнім прагненням досягти гармонії в осяяній Всевишнім блакиті. Проте жорстока дійсність з безкінечним ланцюгом людських страждань примусила його докорити Богові за нездійснення своєї мрії - перетворення "висохлого струмка" на "чарівне озеро", тим самим визнаючи вже свою неминучу загибель на шляху до вічного, неземного, надсвідомого.

У сонеті Малларме виразно простежувався контраст між космічним простором (“l'еspace”) - ірреальним буттям, пронизаного мрією, щастям, радістю, волею ("le vierge, le vivace et le bel aujourd'hui") - та крижаним озером ("le lac dur"), що уособлювало страх відчуження героя та втрату ним свого власного “Я” через покору розуму “порожнечій” дійсності. У свідомості лебедя розуміння приреченості страждання та загибелі (“" Un cygne d'autrefois se souvient que c'est lui / Magnifique mais qui sans espoir se délivre" - "О, лебедю, згадай, який ти був раніше / Прекрасний, але без надії визволитися") переплелися з почуттями покинутості та самотності (“Il s'immobilise au songe froid de mépris / Que vêt parmi l'exil inutile le Cygne" - "Він скував себе холодним сном зневаг, / О, лебедю, в своїм вигнанні непотрібним" $)^{40}$. У цьому ракурсі поет виступив аутсайдером, який вже заздалегідь, на підсвідомому рівні, визнав себе безсилим у фатальній для нього боротьбі із зимовою стихією, що перетворила його на примару в невимушеному вигнанні. Песимістично-настроєвий тон у Малларме створила символіка зими, що відобразила гіркоту нездійснених мрій героя - лебедя, який власноруч прирік себе на невблаганну, неминучу смерть у крижаних прозорих путах льодовика (“le transparent glacier”). У ліриці французького символіста переважав прийом акцентування білого кольору, який мав протилежну символіку, втілюючи ідею збайдужіння, забут-

40 Там само, с. 138. 
тя, порожнечі, безтілесності, мовчання та смерті через зорові ("le lac dur" - "мертве озеро", "le givre" - "іній”, "le transparent glacier" - "прозорий льодовик", "la blanche agonie" - "біла агонія") та дотикові образи ("un coup d'aile ivre" - “удар п’яного крила", “un cygne” - “лебідь”, "l’oiseau” "птах", "le plumage" - “пір'я"). В аналізованому творі Малларме створив символ лебедя-аутсайдера, що дало йому можливість розкрити настроєве тло власної приреченості ліричного героя на самотність, втрати ним індивідуальності, сили та моці, життєвої та творчої реалізації, ілюзії пошуку чогось ірреального через неспроможність власним голосом виспівувати про омріяну країну (“la region où vivre”) в полоні мертвої зими (“l'hiver sterile"), осяяної нудьгою ("l'ennui a resplendi").

Славнозвісний на той час поетичний твір Лебідь Малларме, що став своєрідним літературним маніфестом французького символізму, захоплював перекладачів не тільки своїм глибоким змістом, але й новими засобами поетичної виразності. Одним із перших вірш Лебідь переклав у 1913 році Брюсов, а українська інтерпретація першотвору була репрезентована Михайлом Драй-Хмарою та Миколою Терещенком. У передмові до збірки перекладів Поезії Малларме літературознавець Олег Зуєвський відмітив змістовні відхилення від основної думки французького оригіналу, звернувши увагу на заміну підмета в першому катрені сонету. Керуючись особистою внутрішньою цензурою, підкреслював він, перекладачі першотвору неадекватно передали перший рядок (“le vierge, le vivace et le bel aujourd'hui" - "краси пречистої безсмертний гордий син” (Драй-Хмара); “бессмертный, девственный властитель красоты” (Брюсов); “безсмертний, чарівний, скажи, невинний ти” (Микола Терещенко) замість (“пречистого, радісного і неповторного дня"), надаючи дієву, активну роль саме лебедю, представленого якимсь “«борцем» та «дерзальником»" ${ }^{41}$. Із цього приводу варто зазначити, що саме під впливом твору Лебідь Малларме, який передав його песимістично-настроєвий лейтмотив, пронизаний трагічним відчуттям власної приреченості поета до долі аутсайдера-страдника, Драй-Хмара створив сонет Лебедi (1928) зі своїм ідейно-художнім змістом. Український лірик, виступаючи передусім за розвиток та збереження духовних цінностей та культурних здобутків нації, окреслив першорядну роль митця у заідеологізованому суспільстві, присвятивши маніфестаційний вірш своїм товаришам - поетам-неокласикам (Максиму Рильському, Миколі Зерову, Павлу Филиповичу, Освальду Бургардту, який друкувався під псевдонімом Юрій Клен), що сповідували, як і він, загальнолюдські ідеали.

Митці-символісти намагалися досягнути духовної сфери, співвідносної з творчими інтенціями буття особистості. Дуальність світогляд-

41 Там само, с. 7. 
ної концепції Олександра Олеся, Адама Міцкевича, Казімежа Тетмаєра, Леопольда Стаффа та Федора Сологуба увиразнилася в образі “курного”, "босого", “хворого" поета-паломника - пілігрима, чиї роздуми акцентували ідею шляху в країну мрій - країну прекрасного, у місто "вічної весни” "“Тільки б іти пілігримом / В небо, де світишся ти” (Олесь) $)^{42}$, “С в далях місто, сховане в імлі, / Де у садах буяють вічні весни.../ До нього йду крізь дощ і бурі злі, / I крок легкий мій, і мій спів чудесний...” (Стафф)) $)^{43}$ в контексті маніфестування вольової позиції шукача свободи ("То шаг назад, то два вперед / И чередуясь мерно, дали / Встают все новые пред ним / Неистощимы, как печали, / И все далек Ерусалим" (Сологуб) ${ }^{44}$, який протистоїть конформізму.

Репрезентування романтичного образів поета-мандрівника визначила в поетичній традиції Олександра Олеся та європейських символістів складний емоційно-інтелектуальний стан межі століть й репрезентувала напружені естетичні пошуки літератури як в загальносвітовому контексті, так і в контексті історично обумовленій національно-культурній рефлексії.

\section{ЛІТЕРАТУРА}

Bal'mont Konstantin. 1990. Izbrannoe: Stihotvoreniâ.Perevody. Stat'i. Moskva: Pravda [Бальмонт Константин. 1990. Избранное: Стихотворения. Переводы. Статьи. Москва: Правда].

Blok Aleksandr. 1962. Sobranie sočinenij: v 8-mi t. Red. Orlov V. N. T. 3: Stihotvoreniâ i poèmy (1907-1916). Moskva - Leningrad: Hudožestvennaâ literatura [Блок Александр. 1962. Собрание сочинений: в 8-ми т. Ред. Орлов В. Н. Т. 3: Стихотворения и поэмы (1907-1916). Москва - Ленинград: Художественная литература].

Bodler Šarl'. 1999. Poeziï. Kiїv: Dnìpro [Бодлер Шарль. 1999. Поезї. Київ: Дніпро].

Brûsov Valerij. 1977. Sobranie sočinenij: v 7-h t. T. 1: Stihotvoreniâ (1892-1909). Moskva: Hudožestvennaâ literatura [Брюсов Валерий. 1977. Собрание сочинений: в 7-х m. Т. 1: Стихотворения (1892-1909). Москва: Художественная литература].

Draj-Hmara Mihajlo. 1989. Vibrane. Kiïv: Radâns'kij pis'mennik [Драй-Хмара Михайло. 1989. Вибране. Київ: Радянський письменник].

Ivanov Vâčeslav. 1979. Sobranie sočinenij: v 4-h t. T. 3: Stihotvoreniâ. Red. Ivanov D., Dešart O. Brûssel': Foyer oriental chretien [Иванов Вячеслав. 1979. Собрание сочинений: в 4-х m. Т. 3: Стихотворения. Ред. Иванов Д., Дешарт О. Брюссель: Foyer oriental chretien].

Mallârme Stefan. 1990. Poeziï. Kiïv: Al'berts'kij unìversitet [Маллярме Стефан. 1990. Поезії. Київ: Альбертський університет].

Oles' Oleksandr. 1990. Tvori: v 2 t. T. 1: Poetični tvori. Lirika. Poza zbirkami. Z neopublikovanogo. Satira. Kiïv: Dnìpro [Олесь Олександр. 1990. Твори: в $2 \mathrm{~m}$.

42 О. Олесь, цит. праця, с. 189.

43 Передзвони польської лютні: Поетична антологія..., с. 148.

44 Ф. Сологуб, цит. праця, с. 156. 
Т. 1: Поетичні твори. Лірика. Поза збірками. 3 неопублікованого. Сатира. Київ: Дніпро].

Peredzvoni pol's'koï lûtnì: Poetična antologiâ. 2001. Red. Radiševs'kij R. Kiïv: Osnovi

[Передзвони польської лютні: Поетична антологія. 2001. Ред. Радишевський

Р. Київ: Основи].

Sologub Fedor. 1987. Stihotvoreniâ. Sost. Dikman M. I. Leningrad: Sovetskij pisatel' [Coлогуб Федор. 1987. Стихотворения. Сост. Дикман М. И. Ленинград: Советский писатель].

Staff Leopold. 1967. Poezje zebrane. T. 2. Warszawa: Państwowy Instytut Wydawniczy. Tetmajer Kazimierz. 1980. Poezje. Warszawa: Czytelnik.

Verlen Pol'. 1968. Lirika. Kï̈v: Dnìpro [Верлен Поль. 1968. Лірика. Київ: Дніпро].

\title{
THE IMAGE OF THE ROMANTIC POET-TRAVELER IN THE CREATION OF OLEKSANDR OLES AND EUROPEAN SYMBOLISTS
}

\begin{abstract}
This paper is devoted to the image of the romantic poet-traveler which became the inalienable constituent of the original creation of European symbolists of the end XIX to beginning XX of the century on the background of the European tendencies. Oleksandr Oles and European symbolists brought the idea of the "inner individual". They revolted against the world and the public and government norms. The originality of the system of the artistic images, motives, spirits, rhythm and melodic absorbed the powerful lyricism of the poets' sensitive soul.
\end{abstract}

Keywords: image, nature, symbol, symbolism, motif, soul.

\section{POSTAĆ ROMANTYCZNEGO POETY-WĘDROWNIKA W TWÓRCZOŚCI OLEKSANDRA OŁESIA I SYMBOLISTÓW EUROPEJSKICH}

Streszczenie. Celem niniejszego artykułu jest próba analizy motywu romantycznego poety-wędrowcy, pojawiającego się w twórczości ukraińskiego pisarza Oleksandra Ołesia oraz symbolistów europejskich, w tym także polskich. Badania ujawniły, że w analizowanych utworach poetyckich nastroje człowieka, jego uczucia eksponowane są głównie przy pomocy symboli ornitomorficznych, przedstawiających postawę konfliktu ze światem zewnętrznym, otoczeniem. Autor podjął próbę zdefiniowania sposobu funkcjonowania obrazów pustyni i drogi, będących formantami ogólnych stanów psychologicznych epoki i charakteryzujących przeżycia osobiste podmiotu lirycznego.

Słowa kluczowe: obraz, przyroda, symbol, symbolizm, motyw, dusza. 